\title{
Effect of Different Protein Sources with Different Levels on Growth Performance and Carcass Dissection of Japanese Quail (Coturnix Coturnix Japonica)
}

\author{
Dejeen A. Mohammed ${ }^{\text {a }}$, Jameela H. Salih ${ }^{\text {a, Shekhmous H. Hussen }}{ }^{\text {a,* }}$ \\ ${ }^{\text {a }}$ Dept. of Animal Production, College of Agricultural Engineering Sciences, University of Duhok, Kurdistan Region - Iraq \\ (sheikhmous.hussein@uod.ac)
}

\begin{abstract}
:
The fish meal and soybean meal are the most used protein sources in poultry rations, especially in quail birds due to their higher requirements of crude protein that affecting their growth rate. The objective was to investigate the effect of source of dietary protein and its levels on growth traits, carcass characteristics and some blood parameters. This study was conducted at poultry farm in Duhok city/College of agricultural engineering sciences/Animal production Department/ Kurdistan Region- Iraq, 2020. A total of 360 one-day unsexed chicks of J. quail (Coturnix Coturnix Japonica) were divided equally into two groups (treatments) according to protein source (fishmeal and soybean meal groups), each group involved three levels of crude protein (20,23 and $26 \% \mathrm{CP})$, and each level had three replicates. The birds distributed randomly on the cages which contained 20 birds / replicate. The main results were as follow; fishmeal source of diet protein surpassed significantly soybean in live body weight (LBW), weight gain (WG), feed conversion ratio (FCR) and carcass characteristics. The level of $26 \%$ crude protein (CP) in the diet recorded the best LBW, WG and FCR; while the level of $23 \% \mathrm{CP}$ surpassed both $20 \%$ and $26 \%$ in mortality rate and carcass dissections. However, total protein, hemoglobin and albumen parameters in the blood were not affected significantly $(p>0.05)$ neither by protein source nor by its levels in the quail rations. As conclusion, fish meal was better than soybean meal; and $26 \% \mathrm{CP}$ was the best level.
\end{abstract}

KEYWORDS: Quail, Protein Source, Growth, Carcass, Globulin.

\section{INTRODUCTION}

Japanese quail birds, are small-domesticated avian species, has assumed importance worldwide as laboratory bird and is presently commercially exploited for meat and egg production. In many countries of European and Asian, Japanese bird is considered as one important source for meat yield (Minvielle, 1998; Kayang et al. 2004; Ayasan, 2013). In addition, quail birds are valuable resource for meat and they resistance to hard environmental conditions, therefore nowadays, different lines of quail are reared in Kurdistan region in order to provide the local markets with delicious kinds of meat (Hussen and Salih, 2019). Marks (1993) reported that body weight's coefficient of variation ranged from 15 to $24 \%$ at 28 days old. So, body weight (BW) character is an important trait beside food conversion ratio (FCR) to be improved environmentally (including the nutrition as main affecting factor) for maximizing the yield (Kaur et al. 2008; Baylan et al. 2009). Karaman et al. (2013) stated that males vs. female's body weight of J. quail birds that received soybean meal protein at 1 , 21 and 42 days old were $8.75,111.42$ and 178.13 gm. vs. 9.07, 118.97 and 219.07 gm., respectively.

A protein deficiency in ration, often caused by either one or more limiting essential amino acids (AA) or by inadequate consumption of protein, will result in growth rate, $\mathrm{N}$ retention, feed consumption and utilization (Church, 1991). The protein levels in quail ration, especially of breeder ration is one significant factor for hatching traits and embryonic mortality. A study with Chuker partridge reported that the general tendency increases infertility with protein level of (CP $17 \%$ ), and in contrary hatchability decreased under the same condition (Cufadar et al., 2010). This approach is more closely related to the real AA requirements of poultry species and gives the option for better utilizing of protein by-products different than soybean meal and fish meal. The poultry feeds formulation on the basis of digestible AA in Japanese quails is not adequately studied. However, Lee et al., (1979) and Dahouda et al., (2013) found that quails fed with higher dietary protein level ( 28 percent) during growing period ( $0-5$ weeks) obtained early sexual maturity. The live BW and FCR in Japanese quail are affected significantly by selection, while both WG and FI are not (Drumond, et al., 2015; Hussen et al., 2016); which mean that may be affected by environmental conditions such as quantity and quality of dietary protein.

Vali et al., (2005) concluded that breast percent of quail birds was differed significantly between males and females (39.98 vs. $41.55 \%$, respectively). Bonos et al., (2010), stated that the relative weight of some carcass parts in Japanese quail at 6 weeks of age were $74.52,34.23$ and $22.34 \%$ for carcass, breast and leg, respectively. Also, Kosshak et al., (2014), found that the percentages of dressing carcass, breast and thigh were 78.4, 41.88 and $25.72 \%$, respectively. In recent study on carcass dissection of quail, Hussen, (2020) stated that the percentages of carcass, leg, giblets and back of J. quail (light brown line) at 42 days old were $64.28,15.12,5.07$ and $38.52 \%$, respectively. He added that males surpassed females significantly for all mentioned percent except giblets, in spite of heavier live body weight of females compared to males in J. quail birds.

Most blood parameters were not statistically significant between both sexes of J. quail (light brown birds), and those parameters were correlated to each other significantly (Farahat et al., 2010; Meshabaz et al., 2017). However, the values of 
total protein, albumen and globulin in J. quail blood were 37, 14.4 and $22.56 \mathrm{~g} / 1$, respectively (Meshabaz et al., 2017).

The present study objective is to investigate the effect of source of dietary protein (animal and vegetable) and its levels (20, 23 and $26 \%$ ) on growth traits, carcass characteristics and some blood parameters of J. quail birds (Coturnix coturnix Japonica).

\section{MATERIAL AND METHODS}

\subsection{Management and rearing}

This study was conducted at poultry farm in Duhok city/College of agricultural engineering sciences/Animal production Department/ Kurdistan Region- Iraq. A total of 360 one-day unsexed chicks were brought from private hatchery in Semail on 01 April, 2020; and divided equally into two groups (treatments) according to crude protein (CP) source (fishmeal and soybean meal groups), each group involved three levels of crude protein $(20,23$ and $26 \% \mathrm{CP})$; these levels have been chosen because (NRC, 1994) mentioned $26 \%$ CP for quail which is expensive, so this study tried to find cheaper alternative; and each level had three replicates. The birds distributed randomly on the cages which contained 20 birds / replicate. The chicks were fed on the mentioned dietary treatments from the one-day old up to the end of experiment (35 days old). The ration submitted ad-libitum, and the chemical composition of the diet is illustrated in Table 1, in which the CP with level $26 \%$ was control and formed according to Lesson and Summers (2005). The light was provided as 23 hour/day for the first day, and then decreased the photoperiod one hour per week, to reach at the end of growth period ( 35 days of age or 5 weeks old) to 18 hour / day.
The daily temperature and relative humidity for whole growth period are illustrated in Figure 1.

\subsection{Studied traits and parameters}

The following characters were studied: Live body weight (BW), weight gain (WG), feed intake (FI), feed conversion ratio (FCR), mortality rate (MR), carcass dissection; in addition to investigate some blood parameters (total protein, albumen and globulin).

Carcass dissections were computed as proportions from the live body weight (\%); main carcass characteristics were computed (Carcass, giblets, breast, drumstick and thigh \%) for random samples of three birds from each level within each treatment (group).

Serum total protein and albumin $(\mathrm{g} / \mathrm{dl})$ were determined by using analyzing material (kit) produced by BIOLAB SA, France by using spectrophotometers, for six samples of each level within each treatment (group). Globulin was calculated as the difference between total protein and albumin.

\subsection{Statistical analysis}

The present experiment was designed as factorial CRD, and the collected data were analyzed as factorial analysis $(2 * 3)$ using GLM proc., within SAS software (SAS Institute, 2014) according to the following model:

$$
Y_{i j k}=\mu+P_{i}+L_{j}+(P * L)_{i j}+e_{i j k}
$$

Where: $\boldsymbol{Y}_{i j k}=$ the observation of a trait; $\mu=$ overall mean; $\boldsymbol{P}_{\boldsymbol{i}}=$ The fixed effect of protein source; $\boldsymbol{L}_{j}=$ the level of protein; $\left(P^{*} \boldsymbol{L}\right)_{i j}=$ the interaction between protein source and its level; $\boldsymbol{e}_{i j k}=$ experimental error.

The differences between main group (treatments) and subgroup (levels) means were tested using Duncan multiple range test at 0.05 probability (Duncan, 1955).

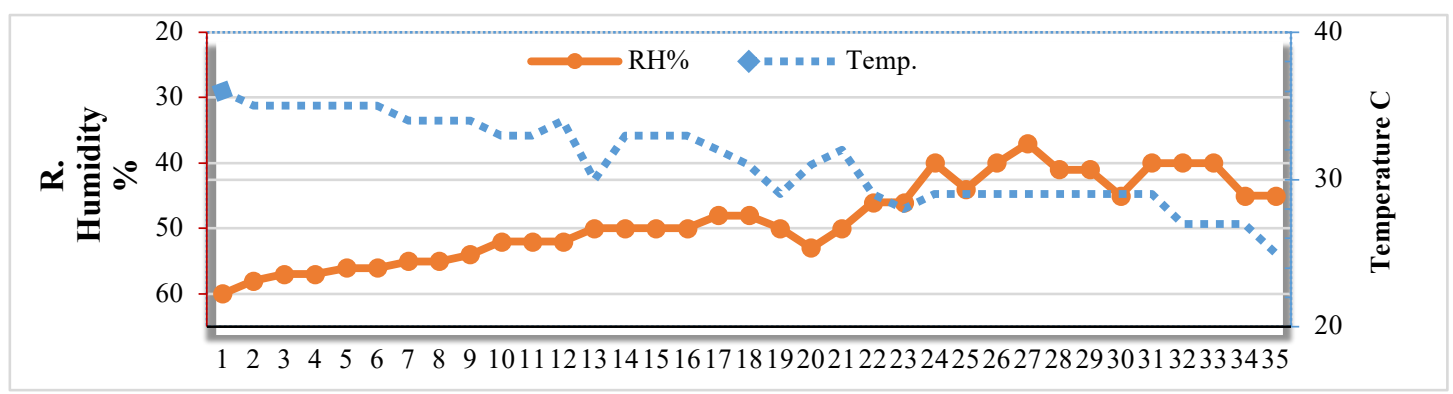

Figure 1. Daily Temperature $\left(\mathrm{C}^{\circ}\right)$ and Relative Humidity (\%) during whole period of experiment

Table 1. Submitted rations to the quail chicks

\begin{tabular}{|l|c|c|c|c|c|c|}
\hline \multirow{2}{*}{\multicolumn{1}{c}{ Ingredient }} & \multicolumn{3}{c|}{ Fish-meal protein } & \multicolumn{3}{c|}{ Soybean-meal protein } \\
\cline { 2 - 7 } & $\mathbf{2 0} \%$ & $\mathbf{2 3} \%$ & $\mathbf{2 6} \%$ & $\mathbf{2 0} \%$ & $\mathbf{2 3} \%$ & $\mathbf{2 6} \%$ \\
\hline Yellow corn & 61 & 55 & 50 & 52 & 42 & 34 \\
\hline Soybean meal (48 \%) & - & - & - & 30 & 39 & 47 \\
\hline Fish meal (60 \%) & 19 & 25 & 30 & - & - & - \\
\hline Wheat grain & 11 & 11 & 11 & 9 & 10 & 10 \\
\hline Wheat bran & 5 & 5 & 5 & 5 & 5 & 5 \\
\hline Vegetable oil & 2 & 2 & 2 & 2 & 2 & 2 \\
\hline Limestone & 1.1 & 1.1 & 1.1 & 1.1 & 1.1 & 1.1 \\
\hline Di-calcium phosphate & 0.1 & 0.1 & 0.1 & 0.1 & 0.1 & 0.1 \\
\hline Mixture vit. \& Min. & 0.3 & 0.3 & 0.3 & 0.3 & 0.3 & 0.3 \\
\hline Salt & 0.5 & 0.5 & 0.5 & 0.5 & 0.5 & 0.5 \\
\hline Total & $\mathbf{1 0 0}$ & $\mathbf{1 0 0}$ & $\mathbf{1 0 0}$ & $\mathbf{1 0 0}$ & $\mathbf{1 0 0}$ & $\mathbf{1 0 0}$ \\
\hline Chemical composition & \multicolumn{7}{|l|}{} & \\
\hline ME k.cal./kg & 3130 & 3099 & 3073 & 2904 & 2798 & 2708 \\
\hline CP \% & 19.8 & 23.07 & 25.82 & 19.83 & 23.05 & 25.9 \\
\hline C. Fiber \% & 2.25 & 2.15 & 2.1 & 4.1 & 4.6 & 4.9 \\
\hline Ether extract & 6.44 & 6.77 & 7 & 4.5 & 4.25 & 4.01 \\
\hline Methionine & 0.34 & 0.39 & 0.43 & 0.33 & 0.37 & 0.4 \\
\hline Lysine & 0.84 & 1.02 & 1.2 & 1.07 & 1.3 & 1.5 \\
\hline
\end{tabular}




\section{RESULTS AND DISCUSSION}

\subsection{Body weight and weight gain}

The results of quail's live body weight as affected by protein source and its levels are presented in Table 2. It could be noticed from the table that just the body weight of the first day old was not affected significantly $(p>0.05)$ by both studied factors, while all the rest studied weeks appeared significant differences between both sources and among the three studied levels of CP \%; where the fish meal as source of animal protein, surpassed significantly $(p \leq 0.01)$ soybean one in all mentioned weeks, except the final studied week which was significant at $(p \leq 0.05)$. Also the level $26 \% \mathrm{CP}$ surpassed $20 \% \mathrm{CP}$ in the first 2 weeks and recorded the superiority on both 20 and $23 \%$ CP for the three final studied weeks. These results insure that the animal source of protein is more suitable for higher body weight in J. quail birds; but unfortunately the fish meal give the quail meat unfavourable taste, beside the high price of the fish meal and animal protein; and the level of $26 \% \mathrm{CP}$ is the best level of protein should be submitted to quail, since quail birds need high crude protein level according to nutritional requirements of quail (NRC, 1994). Regarding the interaction between protein source and its level, Table 2, illustrate that both studied weeks (third and fifth) were not significant, while the weeks (first, second, and fourth) had significant interaction; where the fishmeal interacted with level of $26 \% \mathrm{CP}$ in order to record the highest live body weight of quail. The present finding are in agreement with the results of Marks, (1993); Kaur et al., (2008); Baylan et al., (2009) who found that the 26 $\%$ of $\mathrm{CP}$ in quail ration resulted in best body weights.

Table 2. Body weight (Mean \pm SE) as affected by the treatment and its levels

\begin{tabular}{|c|c|c|c|c|c|c|c|c|}
\hline \multirow{2}{*}{$\begin{array}{c}\text { Age } \\
\text { (week) }\end{array}$} & \multirow{2}{*}{$\begin{array}{l}\text { Treatment } \\
\text { (T) }\end{array}$} & \multicolumn{3}{|c|}{ Levels (L) } & \multirow{2}{*}{$\begin{array}{c}\text { Overall } \\
\text { Mean / T }\end{array}$} & \multicolumn{3}{|c|}{ Sig. $(p)$} \\
\hline & & 20 & 23 & 26 & & $T$ & $\mathbf{L}$ & $T * L$ \\
\hline \multirow{3}{*}{$\mathbf{0}$} & Fish meal & $7 \pm 0.0$ & $7.38 \pm 0.0$ & $7.5 \pm 0.0$ & 7.29 & \multirow{3}{*}{ NS } & \multirow{3}{*}{ NS } & \multirow{3}{*}{ NS } \\
\hline & Soybean & $7 \pm 0.0$ & $7.13 \pm 0.0$ & $7.25 \pm 0.0$ & 7.13 & & & \\
\hline & Overall/ L & 7 & 7.26 & 7.38 & & & & \\
\hline \multirow{3}{*}{1} & Fish meal & $20.34 \pm 0.56^{\mathrm{b}}$ & $23.71 \pm 0.84^{\mathrm{a}}$ & $24.13 \pm 0.93^{\mathrm{a}}$ & $22.72 \mathrm{~A}$ & \multirow{3}{*}{$* *$} & \multirow{3}{*}{$* *$} & \multirow{3}{*}{ * } \\
\hline & Soybean & $18.21 \pm 0.26^{\mathrm{c}}$ & $18.5 \pm 0.22^{\mathrm{c}}$ & $18.65 \pm 0.37^{\mathrm{bc}}$ & 18.45 B & & & \\
\hline & Overall/ L & 19.27 B & $21.11 \mathrm{~A}$ & $21.39 \mathrm{~A}$ & & & & \\
\hline \multirow{3}{*}{2} & Fish meal & $28.83 \pm 1.12^{\mathrm{c}}$ & $32.15 \pm 0.3^{b}$ & $37.90 \pm 1.55^{\mathrm{a}}$ & $32.96 \mathrm{~A}$ & \multirow{3}{*}{$* *$} & \multirow{3}{*}{ ** } & \multirow{3}{*}{ ** } \\
\hline & Soybean & $28.54 \pm 0.4^{\mathrm{c}}$ & $32.09 \pm 0.84^{\mathrm{b}}$ & $30.17 \pm 1.18^{b}$ & 30.27 B & & & \\
\hline & Overall/ L & 28.69 B & $32.11 \mathrm{~A}$ & $34.03 \mathrm{~A}$ & & & & \\
\hline \multirow{3}{*}{3} & Fish meal & $61.31 \pm 1.61$ & $64.95 \pm 0.97$ & $75.14 \pm 1.1$ & $67.13 \mathrm{~A}$ & \multirow{3}{*}{$* *$} & \multirow{3}{*}{$* *$} & \multirow{3}{*}{ NS } \\
\hline & Soybean & $51.55 \pm 1.24$ & $58.57 \pm 2.0$ & $59.23 \pm 3.48$ & 56.45 B & & & \\
\hline & Overall/ L & $56.43 \mathrm{C}$ & $61.76 \mathrm{~B}$ & $67.19 \mathrm{~A}$ & & & & \\
\hline \multirow{3}{*}{4} & Fish meal & $95.81 \pm 2.8^{c}$ & $103.75 \pm 0.6^{\mathrm{b}}$ & $118.48 \pm 0.5^{\mathrm{a}}$ & 106.01 A & \multirow{3}{*}{$* *$} & \multirow{3}{*}{ ** } & \multirow{3}{*}{$* *$} \\
\hline & Soybean & $92.15 \pm 1.1^{\mathrm{d}}$ & $96.72 \pm 0.24^{\mathrm{c}}$ & $97.01 \pm 1.78^{\mathrm{c}}$ & $95.29 \mathrm{~B}$ & & & \\
\hline & Overall/ L & $93.98 \mathrm{C}$ & 100.24 B & $107.75 \mathrm{~A}$ & & & & \\
\hline \multirow{3}{*}{5} & Fish meal & $122.72 \pm 3.76$ & $127.5 \pm 3.17$ & $145.10 \pm 2.43$ & 131.77 A & \multirow{3}{*}{ * } & \multirow{3}{*}{$* *$} & \multirow{3}{*}{ NS } \\
\hline & Soybean & $119.27 \pm 5.62$ & $120.14 \pm 0.6$ & $131.87 \pm 4.72$ & 123.76 B & & & \\
\hline & Overall / L & $120.99 \mathrm{~B}$ & 123.82 B & $138.48 \mathrm{~A}$ & & & & \\
\hline
\end{tabular}

Different bold letters ( $A, B$ and $C$ ) in columns and rows; and superscript letters ( $a, b, c$ and $d)$ in rows within each studied age are differ significantly; $T=$ Treat; $L=$ Level.

In respect to weight gain (WG) trait, Figure 2 shows the changes in WG as affected by protein source and its level, during two main periods (from 0-21 days old and from 0-35 days old). It could be observed from the mentioned Figure 2, that the differences between both protein sources and among three studied levels were significant $(p \leq 0.05)$ just for the period from 0-21 days; where fishmeal source surpassed soybean source and the level of $26 \% \mathrm{CP}$ surpassed both 23 and $20 \%$; while the other studied period (0-35 days) was not significant $(p>0.05)$. These results are in agreement with the findings of Kaur et al., (2008); Baylan et al., (2009) who found that the 26 $\%$ of $\mathrm{CP}$ in quail ration resulted in best weight gain.

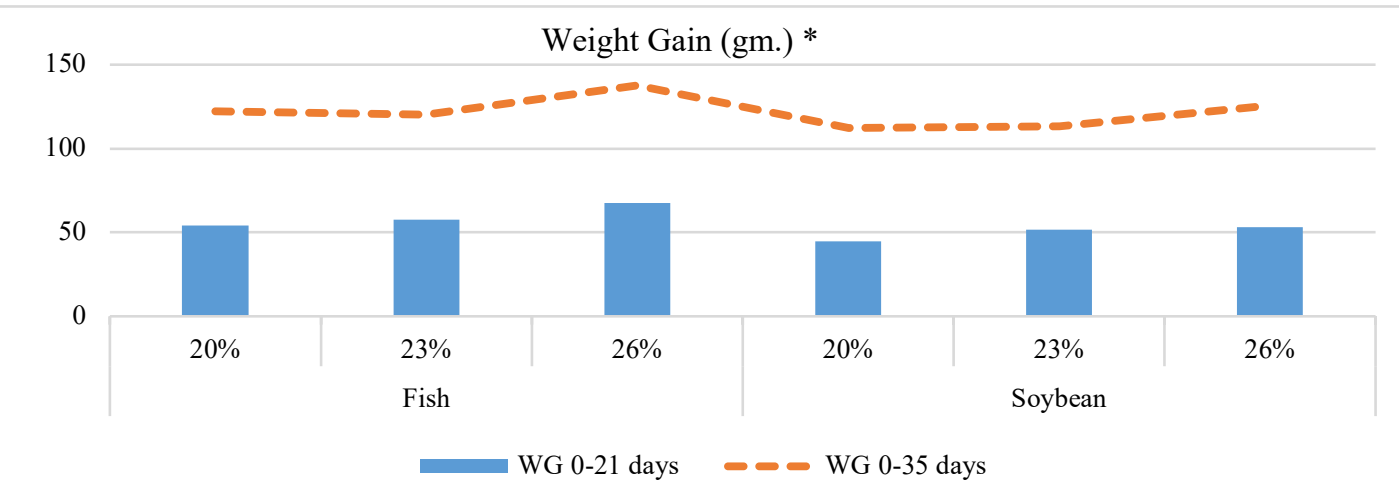

*The differences between both protein sources and among three studied levels were significant just for the period from 0-21 days $(p<0.05)$

Figure 2. Weight gain (average per bird) as affected by protein source and levels 


\subsection{Feed Intake and Feed Conversion Ratio}

The average feed intake per bird during the period from 0-21 days old and also from 0-35 days of age are presented in Figure 3 . It could be noticed from the mentioned Figure that both studied periods were differed significantly $(p \leq 0.05)$ between both studied sources and among the three studied levels. Where in the first growth period, the quail birds consumed feed that containing fish meal more than its soybean counterpart, which may due to its palatability; and the $26 \%$ level recorded the lowest consumed amount of feed in fish meal diets, while in the soybean diet, the lowest amount of consumed feed by birds was recorded in the level $20 \%$, which may related with their body weights. In the second growth period (0-35 days old), the fish meal diet was less consumed by birds compared to soybean one; and $26 \%$ level was recorded the highest consumed amount of feed for both studied sources, this may reflect the needs of birds to more protein concentrations in last growth period.
These results are in agreement with the findings of Cufadar et al., (2010); Dahouda et al., (2013).

In respect to feed conversion ratio (FCR), the diet with soybean source recorded in general better FCR than fish meal diet in both studied periods, which may related with the bird's live body weight; also the level of $26 \% \mathrm{CP}$, recorded the best FCR in both studied periods; but the last level was significantly more active in fish meal diet (Figure 4), which indicates to the significant interaction between this level $(26 \%)$ and fish meal source of crude protein. This result reflect the conclusion of such researches, where if the fish meal submitted to the quail diets as source of crude protein, it should be in $26 \%$ level to obtain the optimum growth rate. However, the findings of Lee et al., (1979); Church, (1991) were similar to the present results.

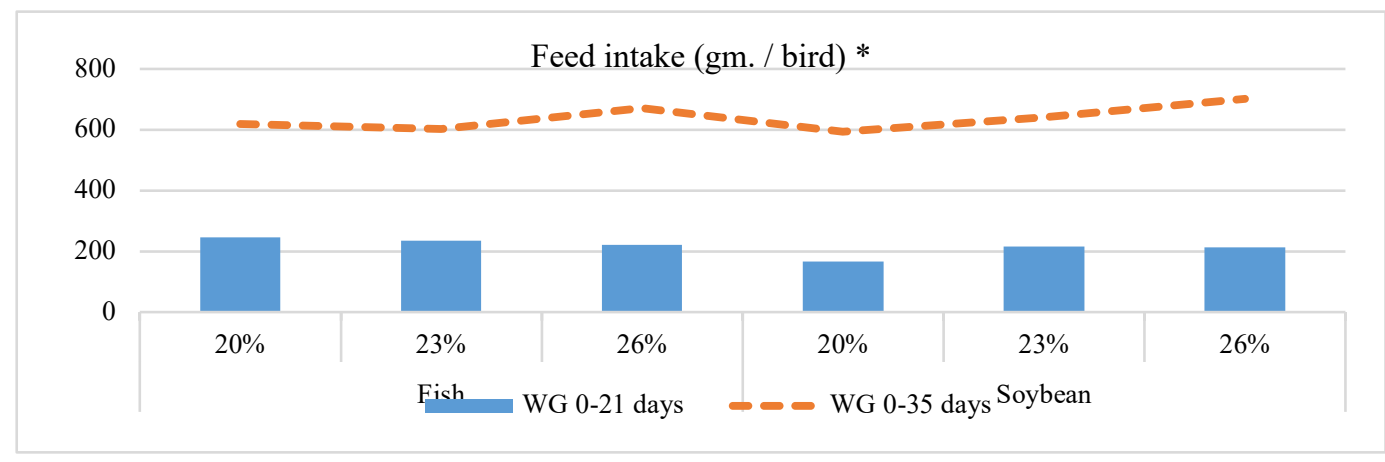

* The differences between both protein sources and among three studied levels were significant for both studied periods $(p<0.05)$

Figure 3. Feed intake (average per bird) as affected by protein source and levels

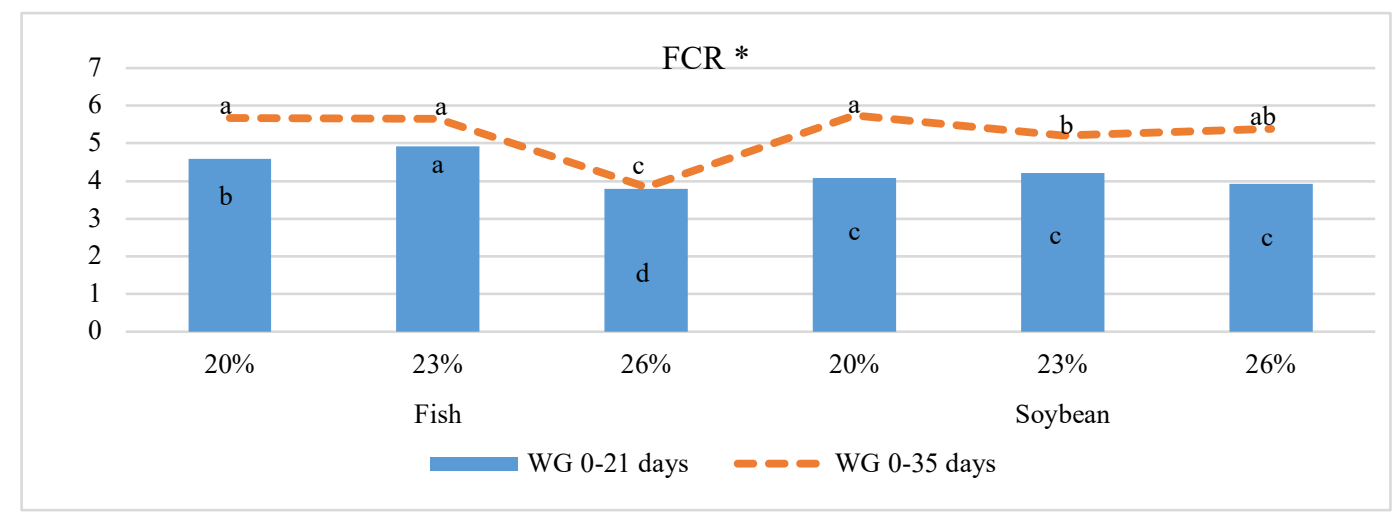

* The interaction between protein source and its level was significant for both studied periods $(p<0.05)$

Figure 4. Feed conversion ratio as affected by protein source and levels

\subsection{Mortality}

The differences between / among the observations of mortality rates for the quail birds of both main treatments (protein source effect), its levels and their interaction were non-significant ( $p>0.05)$ for the growth period (0-35 days old) as illustrated in
Figure 5. In general, it could be noticed from the mentioned Figure that the fish meal diet recorded the same mortality rate for the three studied levels; while the soybean meal diet with level $20 \%$ CP was recorded the highest mortality rate $(26.7 \%)$ compared to the other ( $19.3 \& 25.3 \%$ ) for $23 \%$ and $26 \%$ level, respectively. However, Hussen and Salih, (2019) found similar findings. 


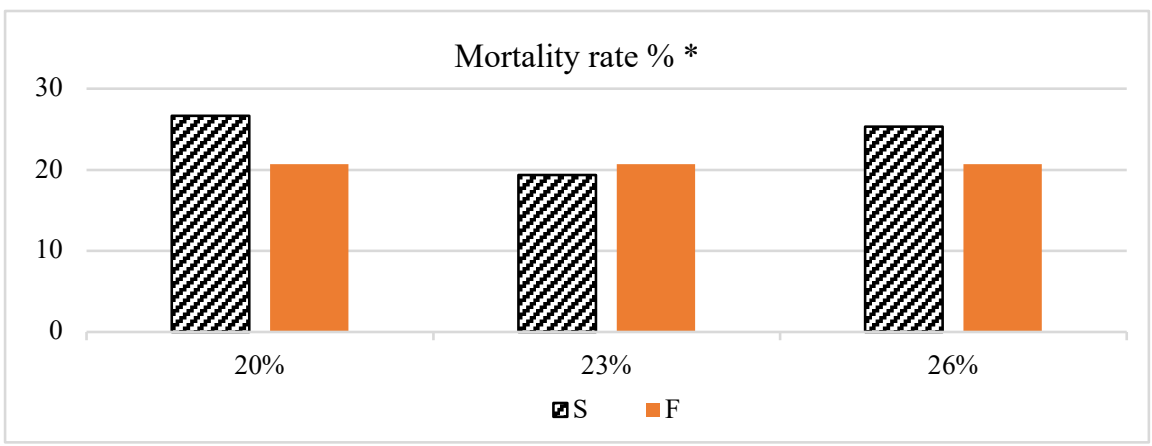

* The differences between protein sources (soybean-S and fish meal-F), its levels and their interaction were not significant.

Figure 5. Mortality rate (\%) as affected by protein sources and levels

\subsection{Carcass characteristics}

The findings of carcass traits of the studied birds are presented in Table (3). In respect to the effect of protein source on the studied carcass characters, it could be observed that LBW and drumstick percentages were not affected significantly $(p>0.05)$, while thigh $\%$ was affected significantly $(p<0.05)$ and the rest studied characters were also affected significantly $(p<0.01)$; where fish meal diet surpassed the soybean one. Regarding the effect of studied levels of CP on studied carcass traits, it could be noticed from the mentioned Table, that all studied characters were affected significantly $(p<0.01)$ except thigh $\%$ which affected significantly at low level $(p<0.05)$; where the level of $23 \%$ surpassed both rest levels ( $20 \& 26 \%)$ except LBW which recorded the highest value at $26 \% \mathrm{CP}$. The interaction between protein source and its level were highly significant $(p<0.01)$ except for thigh $\%$, which was not significant $(p<0.05)$; the interaction showed that the level of $23 \%$ within fish meal diet surpassed most studied carcass traits. However, the present results are generally in agreement with the findings of Bonos et al., (2010); Kosshak et al., (2014); Hussen, (2020).

Table 3. Carcass dissections ( $\%$ Mean \pm SE) as affected by the treatment and its levels

\begin{tabular}{|c|c|c|c|c|c|c|c|c|}
\hline \multirow{2}{*}{ Trait } & \multirow{2}{*}{$\begin{array}{l}\text { Treatment } \\
\text { (T) }\end{array}$} & \multicolumn{3}{|c|}{ Levels (L) } & \multirow{2}{*}{$\begin{array}{l}\text { Overall } \\
\text { Mean / T }\end{array}$} & \multicolumn{3}{|c|}{ Sig. $(p)$} \\
\hline & & 20 & 23 & 26 & & $\mathbf{S}$ & $\mathbf{L}$ & $S * L$ \\
\hline \multirow{3}{*}{ LBW } & Fish meal & $144.7 \pm 6.9^{\mathrm{bc}}$ & $135.7 \pm 4.1^{\mathrm{c}}$ & $206.0 \pm 7.4^{\mathrm{a}}$ & 162.11 & \multirow{3}{*}{ NS } & \multirow{3}{*}{$* *$} & \multirow{3}{*}{ ** } \\
\hline & Soybean & $157.3 \pm 8.5^{\mathrm{b}}$ & $155 \pm 5.6^{\mathrm{b}}$ & $152.33 \pm 8.6^{b}$ & 154.89 & & & \\
\hline & Overall/ L & $151 \mathrm{~B}$ & 145.33 B & 179.17 A & & & & \\
\hline \multirow{3}{*}{ Giblets } & Fish meal & $11.98 \pm 0.9^{\mathrm{a}}$ & $11.15 \pm 0.5^{\mathrm{a}}$ & $8.02 \pm 0.4^{\mathrm{c}}$ & $10.38 \mathrm{~A}$ & \multirow{3}{*}{$* *$} & \multirow{3}{*}{ ** } & \multirow{3}{*}{ ** } \\
\hline & Soybean & $6.12 \pm 0.4^{\mathrm{d}}$ & $10.2 \pm 0.4^{\mathrm{ab}}$ & $9.29 \pm 0.5^{b}$ & $8.55 \mathrm{~B}$ & & & \\
\hline & Overall/ L & $9.05 \mathrm{~B}$ & $10.69 \mathrm{~A}$ & $8.65 \mathrm{~B}$ & & & & \\
\hline \multirow{3}{*}{ drumstick } & Fish meal & $5.79 \pm 0.3^{\mathrm{ab}}$ & $6.25 \pm 0.1^{\mathrm{a}}$ & $5.33 \pm 0.1^{b}$ & 5.79 & \multirow{3}{*}{ NS } & \multirow{3}{*}{ ** } & \multirow{3}{*}{ ** } \\
\hline & Soybean & $4.87 \pm 0.3^{\mathrm{c}}$ & $\mathbf{6 . 5 5} \pm 0.3^{\mathrm{a}}$ & $5.79 \pm 0.2^{\mathrm{ab}}$ & 5.74 & & & \\
\hline & Overall/ L & $5.33 \mathrm{~B}$ & $6.39 \mathrm{~A}$ & $5.56 \mathrm{~B}$ & & & & \\
\hline \multirow{3}{*}{ Thigh } & Fish meal & $9.03 \pm 0.3$ & $10.17 \pm 0.5$ & $8.54 \pm 0.2$ & $9.25 \mathrm{~A}$ & \multirow{3}{*}{ * } & \multirow{3}{*}{ * } & \multirow{3}{*}{ NS } \\
\hline & Soybean & $8.19 \pm 0.6$ & $8.87 \pm 0.1$ & $8.69 \pm 0.2$ & 8.58 B & & & \\
\hline & Overall/ L & $8.61 \mathrm{~B}$ & $9.52 \mathrm{~A}$ & $8.61 \mathrm{~B}$ & & & & \\
\hline \multirow{3}{*}{ Breast } & Fish meal & $25.55 \pm 0.9^{b}$ & $26.51 \pm 0.6^{\mathrm{a}}$ & $25.57 \pm 0.7^{b}$ & $25.87 \mathrm{~A}$ & \multirow{3}{*}{$* *$} & \multirow{3}{*}{ ** } & \multirow{3}{*}{ ** } \\
\hline & Soybean & $19.25 \pm 1.4^{\mathrm{d}}$ & $26.47 \pm 0.5^{\mathrm{a}}$ & $23.22 \pm 0.5^{\mathrm{c}}$ & 22.98 B & & & \\
\hline & Overall/ L & $22.4 \mathrm{C}$ & $26.49 \mathrm{~A}$ & 24.39 B & & & & \\
\hline \multirow{3}{*}{$\begin{array}{l}\text { Dressing } \\
\text { Carcass }\end{array}$} & Fish meal & $67.39 \pm 1.9^{b}$ & $70.17 \pm 1.4^{\mathrm{a}}$ & $61.9 \pm 1.2^{\mathrm{c}}$ & $66.49 \mathrm{~A}$ & \multirow{3}{*}{$* *$} & \multirow{3}{*}{ ** } & \multirow{3}{*}{ ** } \\
\hline & Soybean & $51.16 \pm 2.6^{\mathrm{d}}$ & $67.39 \pm 0.9^{b}$ & $61.64 \pm 0.9^{\mathrm{c}}$ & 60.06 B & & & \\
\hline & Overall / L & 59.28 B & $68.78 \mathrm{~A}$ & 61.77 B & & & & \\
\hline
\end{tabular}

Different bold letters ( $A, B$ and $C$ ) in columns and rows; and superscript letters $(a, b, c$ and $d)$ in rows within each studied trait are differ significantly; $T=$ Treat; $L=$ Level.

\subsection{Blood parameters}

Table (4) presented the results of some blood parameters for the quail birds fed two protein sources with three levels for each. The results show that the three studied parameters were not affected significantly $(p>0.05)$ by protein source, level and their interaction. This may due to the metabolism nature of quail which digest and metabolic the requirement protein diet and the rest did not store in the body. Any way the present results are generally in agreement with findings of Farahat et al., (2010); Meshabaz et al., (2017). 
Table 4. Blood parameters (Mean $\pm \mathrm{SE})$ as affected by the treatment and its levels $(\mathrm{ml} / \mathrm{dl})$

\begin{tabular}{|c|c|c|c|c|c|c|c|c|}
\hline \multirow[b]{2}{*}{$\begin{array}{l}\text { Para- } \\
\text { meter }\end{array}$} & \multirow[b]{2}{*}{ Treatment } & \multicolumn{3}{|c|}{ Level } & \multirow[b]{2}{*}{$\begin{array}{l}\text { overall } \\
\text { mean } \mathbf{T}\end{array}$} & \multicolumn{3}{|c|}{ sig. $(p)$} \\
\hline & & $20 \%$ & $23 \%$ & $26 \%$ & & $\mathrm{~T}$ & $\mathrm{~L}$ & $\mathrm{~T} * \mathrm{~L}$ \\
\hline \multirow{3}{*}{ 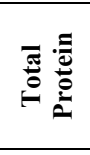 } & Soybean & $3.25 \pm 0.29$ & $3.15+0.26$ & $3.02+0.09$ & 3.14 & \multirow[b]{3}{*}{ NS } & \multirow[b]{3}{*}{ NS } & \multirow[b]{3}{*}{ NS } \\
\hline & Fish & $3.17+0.17$ & $2.78+0.18$ & $3.55+0.44$ & 3.17 & & & \\
\hline & overall mean $\mathbf{L}$ & 3.21 & 2.97 & 3.28 & & & & \\
\hline \multirow{3}{*}{ 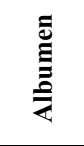 } & Soybean & $0.3+0.04$ & $0.3+0.036$ & $0.3+0.04$ & 0.3 & \multirow[b]{3}{*}{ NS } & \multirow[b]{3}{*}{ NS } & \multirow[b]{3}{*}{ NS } \\
\hline & Fish & $0.35+0.02$ & $0.35+0.04$ & $0.35+0.02$ & 0.35 & & & \\
\hline & overall mean $\mathbf{L}$ & 0.33 & 0.33 & 0.33 & & & & \\
\hline \multirow{3}{*}{$\overline{\bar{z}} . \equiv$} & Soybean & $2.95+0.28$ & $2.85+0.26$ & $2.72+0.09$ & 2.84 & \multirow[b]{3}{*}{ NS } & \multirow[b]{3}{*}{ NS } & \multirow[b]{3}{*}{ NS } \\
\hline & Fish & $2.82+0.17$ & $2.43+0.19$ & $3.2+0.44$ & 2.82 & & & \\
\hline & overall mean $\mathbf{L}$ & 2.88 & 2.64 & 2.96 & & & & \\
\hline
\end{tabular}

\subsection{Economic comparison}

Table (5), illustrate the economic comparison between both studied protein sources, including the studied levels. The economic study carried out according to (Hussen, 2000). The prices of ingredients that were not common among used diets brought from the site of fishmeal vs Soybean meal -price rate (IndexMundi, 2020) and Iraqi local market (personal communication). However, the price per ton of the yellow corn, fishmeal, soybean meal and wheat grain ingredients were 200, $1477.77,406.14$ and 336 \$, respectively. The mentioned Table represents all details of price and cost according to the percentage of used ingredient for studied levels within each studied source. Moreover, as comparison between fishmeal source of crude protein and its soybean counterpart, it could be noticed that the average cost of soybean meal represent just $53.4 \%$ of the fishmeal diet cost if the latter considered as standard (100\%); while the average body weight of birds fed soybean meal represent $92.2 \%$ of the fishmeal counterpart. So, and from the economic point of view it should suggest the using of soybean meal in quail diets instead of fishmeal to obtain best economic revenue.

Table 5. Economic comparison between fish and soybean meals

\begin{tabular}{|l|c|c|c|c|c|c|}
\hline & \multicolumn{3}{|c|}{ Fish-meal protein diet } & \multicolumn{3}{c|}{ Soybean-meal protein diet } \\
\hline Un-common Ingredients & $\mathbf{2 0 \%}$ & $\mathbf{2 3 \%}$ & $\mathbf{2 6 \%}$ & $\mathbf{2 0 \%}$ & $\mathbf{2 3 \%}$ & $\mathbf{2 6 \%}$ \\
\hline Yellow corn & 122 & 110 & 100 & 104 & 84 & 68 \\
\hline Soybean meal (48 \%) & 0 & 0 & 0 & 121.84 & 158.39 & 190.88 \\
\hline Fish meal (60 \%) & 280.77 & 369.44 & 443.33 & 0 & 0 & 0 \\
\hline Wheat grain & 36.96 & 36.96 & 36.96 & 30.24 & 33.6 & 33.6 \\
\hline Cost/ton diet & $\mathbf{4 3 9 . 7 3}$ & $\mathbf{5 1 6 . 4 0}$ & $\mathbf{5 8 0 . 3}$ & $\mathbf{2 5 6 . 1}$ & $\mathbf{2 7 5 . 9 9}$ & $\mathbf{2 9 2 . 4 9}$ \\
\hline Price /kg & 0.4397 & 0.5164 & 0.580 & 0.256 & 0.2759 & 0.2924 \\
\hline Total Feed Intake (gm.) & 618.78 & 603.29 & 670.5 & 539.47 & 641.67 & 701.5 \\
\hline Total cost (except the common ingredients) & 0.27 & 0.31 & 0.39 & 0.14 & 0.18 & 0.21 \\
\hline Final body weight (gm.) & 122.72 & 127.5 & 145.1 & 119.27 & 120.14 & 123.76 \\
\hline Cost- cost ratio & $\mathbf{1 0 0}$ & $\mathbf{1 0 0}$ & $\mathbf{1 0 0}$ & $\mathbf{5 0 . 7 7}$ & $\mathbf{5 6 . 8 5}$ & $\mathbf{5 2 . 7 3}$ \\
\hline Weight-weight ratio & $\mathbf{1 0 0}$ & $\mathbf{1 0 0}$ & $\mathbf{1 0 0}$ & $\mathbf{9 7 . 1 9}$ & $\mathbf{9 4 . 2 3}$ & $\mathbf{8 5 . 2 9}$ \\
\hline
\end{tabular}

\section{CONCLUSION}

It could be concluded from the present study that quail diet with soybean meal source of crude protein is better than fishmeal counterpart for most economic characters. Also, the level of 26 $\% \mathrm{CP}$ is resulted in perfect findings for $\mathrm{BW}, \mathrm{WG}$, and FCR; while the level $23 \%$ was suitable for carcass characteristics.

\section{REFERENCES}

Ayasan,T. 2013. Effects of dietary inclusion of protexin (probiotic) onhatchability of Japanese quails. Indian Journal of Animal Sciences 83 (1): 78-81.

Baylan, M., Canogullari, S., Sahin, A., Copur, G., and Baylan, M. 2009. Effects of different selection methods for body weight on some genetic parameters. J. Anim. Vet. Adv. 8:1385-1391.
Bonos, E.M., Christaki, E.V., and Florou-Paneri, P.C. 2010. Performance and carcass characteristics of Japanese quail as affected by sex or manna oligosaccharides and calcium propionate. The South African Journal of Animal Science, Vol. 40 (3), 173-184.

Church, D.C. 1991. The nutrients, their metabolism, and feeding standards. In: Church, D.C. (ed.) Livestock Feeds and Feeding, $3^{\text {rd }}$ ed. Prentice Hall. Englewood Cliffs, New Jersey.

Cufadar, Y., Olgun, O., Bahtiyarca, Y., and Yıldı, A.O. 2010. Effects of dietary energy and protein on performance, reproduction traits and nitrogen-excretion of breeder chukar partridges (Alectoris chukar). Revue de Medicine Veterinaire; 161(4):151-156.

Dahouda, M., Adjolohoun, S., Montchowul, E.H., Senou, M., and Hounsou, N.M.D. 2013. Growth Performance Of Quail (Conturnix conturnix) Fed On Diet Containing Either Animal Or Vegetable Protein Sources. International Journal of Poultry Sciences 13(7):398-400. 
Drumond, E.S.C., Pires, A.V., Veloso, R.C., Bonafe, C.M., Pereira, I.G., Costa, L.S., Abreu, L.R.A. 2015. Performance of meat type quails in diallel cross. Arq. Bras. Med. Vet. Zootec; 67 (1): $235-241$

Duncan, D.B. 1955. Multiple range and multiple F tests. Biometrics, 11: $1-42$.

Farahat, G. S. Nadia, M., and Omhashem, Y. M. 2010. Genetic parameter estimates for glutathione peroxidase and some blood constituents and their association with some growth traits in Japanese quail. Egypt. poult. Sci. (30) (iii): (847-873).

Hussen, S. H. 2000. Interaction between some environmental factors and different genotypes in some Egyptian local strains of chickens. Ph.D. thesis, Ain Shams Univ., Faculty of Agric. Cairo, Egypt

Hussen, S. H. 2020. Carcass Characteristics in Three Lines of Quail (Coturnix coturnix spp) and Their Crosses II- The Percentages. Syrian Journal of Agricultural Research - SJAR 7(3): 454466.

Hussen, S.H. Abdulrahman, Al-Khdri1 A.M., and Hassan, A.M. 2016 Response to Selection for Body Weight in Japanese quail (Coturnix coturnix japonica). Iranian Journal of Applied Animal Science 6(2), 453-459.

Hussen, S.H. and Saleh, J. H. 2019. Comparison among three quail (Coturnix coturnix spp) lines in their productive performance. Syrian Journal of Agricultural Research - SJAR 6(4): 516527.

IndexMundi, 2020. Fishmeal vs Soybean meal- price rate of change comparison. https://www.indexmundi.com/commodities/?commodity =fish- meal\&commodity=soybean-meal

Karaman, E., Narinc, D., Firat, M.Z. and Aksoy, T. 2013. Nonlin-ear mixed effects modeling of growth in Japanese quail. Poult. Sci. 92, 1942-1948.

Kaur, S., Mandal, A.B., Singh, K.B., and Kadam, M.M. 2008. The response of Japanese quails (heavy body weight line) to dietary energy levels and graded essential amino acid levels on growth performance and immuno-competence. Livest. Sci. 117:255262.

Kayang, B.B., Vignal, A., Inoue-Murayama, M., Miwa, M. Monvoisin, J.L., Ito, S., and Minvielle. E. 2004. A first generation micro satellite linkage map of the Japanese quail. Anim. Genetics, 35: 195-200.

Kosshak, A.S., Dim, N.I., Momoh, O.M., and Gambo, D. 2014. Effect of sex on carcass characteristics and correlation of body weight and blood components in Japanese quails. Journal of Agriculture and Veterinary Science (IOSR-JAVS). Volume 7(11), Ver. III, PP 72-76.

Lee,T.K, Shim, K.F., and Tan, E.L. 1979. Part III. Interaction of Protein levels during the growing and laying periods for Japanese quail. Singapore J. Prim. Ind.,7(3): 6976.

Lesson, S. and Summers, J.D. 2005. Commercial poultry nutrition, 3rdedition, University books, P. O. Box. 1326, Guelph, Ontario, Canada ISBN 978-1-904761-78-5.

Marks, H.L. 1993. Divergent selection for growth in Japanese quail under split and complete nutritional environments. 6 . Differential body weights in reciprocal crosses. Poult. Sci. 72: (in press).

Meshabaz, R.A., Sulaiman, K.M., Hussen S.H., Berwary, M.S., Saleh, J.H., Ahmed, S.A., and Mohammed, N, J. 2017. Hematological study in three lines of quail and their crosses. Science Journal of University of Zakho, 5(3), 249-253.

Minvielle, F. 1998. Genetics and breeding of Japanese quail for production around the world 6th Proc. Asian Poult. Congr., World's Poult. Sci. Assoc., Japan Branch, Nagoya, pp. 122-127.

NRC. 1994. Nutrient Requirements of Domestic Animals.-Nutrient Requirements of Poultry. National Research Council, National Academy Press, Washington, DC

SAS Institute. (2014). Statistical Analysis System (SAS, institute, Inc.), version 9.4. Cary NC, USA.

Vali,,N., Edris, M.A., and.Rahmani, H.R. 2005. Comparison between hatching of two quail strains. Pakistan J.Biolog.Sci., 8 (7): 1062-1063. 